\title{
Chromato-mass-spectroscopic research of chemical composition of Elaeagnus angustifolia L.
}

\author{
O. I. Panasenko (D)1,E,F, V. I. Mozul11,A,B, O. M. Denysenko ${ }^{1, A, E}$, I. I. Aksonova (D)1,C,D , T. V. Oberemko ${ }^{2, C}$ \\ 'Zaporizhzhia State Medical University, Ukraine, 'LLC “PMD-UKRAINE”, Kyiv
}

A - концепція та дизайн дослідження; B - збір даних; C - аналіз та інтерпретація даних; D - написання статті; E - редагування статті; F - остаточне затвердження статті

The aim of the work was chromato-mass-spectroscopic research of chemical composition of Elaeagnus angustifolia L. fruits and leaves and identifying further prospects for the use of this plant in medicine.

Materials and methods. Raw materials of Elaeagnus angustifolia L. were selected as objects of study. The tincture was obtained by maceration and the raw material was extracted with methyl alcohol at room temperature for 10 days according to the method of making tinctures. The study of the chemical composition of Elaeagnus angustifolia L. was carried out using gas chromatograph Agilent $7890 \mathrm{~B}$ GC System (Agilent, Santa Clara, CA, USA) with mass spectrometric detector Agilent 5977 BGC/MSD (Agilent, Santa Clara, CA, USA) and chromatographic column DB-5ms (30 m × $250 \mathrm{mkm} \times 0,25 \mathrm{mkm})$.

Results. 23 compounds ( 1 in the isomeric state) in fruits and 20 compounds ( 2 in the isomeric state) in the leaf of Elaeagnus angustifolia L. were identified. The main components of fruits were sitosterol (phytosterols) $-12.53 \%$, propyl acetate (esters of carboxylic acids) $12.60 \%$, chamazulene (terpenes) $-11.97 \%$ and palmitic acid (fatty acids) $-8.28 \%$. The main component of leaves were sitosterol (phytosterols) - $17.57 \%, 1$-(2-hydroxy-5-methylphenyl)-ethanone (ketone) $-8.35 \%$, phytol (terpenes) $-6.10 \%$. It is known from the literature that chamazulene has antioxidant, antinociceptive, cytotoxic activity. Sitosterol has anti-inflammatory and antidiabetic activity. Hexadecanoic (palmitic) acid has antimicrobial, antidiabetic and antioxidant properties. Phytol is characterized by a wide range of biological action - antimicrobial, antinociceptive, anti-inflammatory, antioxidant and cytotoxic.

Conclusions. Based on the above, the olive can be considered as a source of antimicrobial, antinociceptive, anti-inflammatory, antioxidant, antidiabetic and cytotoxic drugs.

Key words: Elaeagnus angustifolia, GS-MS, antimicrobial action, antidiabetic action, antinociceptive action, cytotoxic action, antiinflammatory action, biological activity.

Актуальні питання фармацевтичної і медичної науки та практики. 2021. Т. 14, № 2(36). С. 179-184

\section{Хромато-мас-спектроскопічне дослідження хімічного складу маслинки вузьколистої Elaeagnus angustifolia L.}

\section{О. І. Панасенко, В. І. Мозуль, О. М. Денисенко, І. І. Аксьонова, Т. В. Оберемко}

Мета роботи - хромато-мас-спектроскопічне дослідження хімічного складу маслинки вузьколистої плодів і листя та виявлення перспектив застосування цієї рослини в медицині.

Матеріали та методи. Об'єкти дослідження - маслинки вузьколистої плоди та листя. Настоянку одержали методом мацерації, сировину екстрагували метиловим спиртом за кімнатної температури протягом 10 днів згідно з методикою виготовлення настоянок. Хімічний склад Elaeagnus angustifolia L. вивчали за допомогою газового хроматографа Agilent 7890B GC System (Agilent, Санта-Клара, Каліфорнія, США) з мас-спектрометричним детектором Agilent 5977 BGC/MSD (Agilent, Santa Clara, CA, CША) та хроматографічної колонки DB-5ms (30 м × 250 мкм × 0,25 мкм).

Результати. Ідентифікували 23 сполуки (одна в ізомерному стані) у плодах, 20 сполук (дві в ізомерному стані) в листі маслинки вузьколистої. Головні складові плодів: ситостерол (фітостероли) - 12,53 \%, пропіл ацетат (естери карбонових кислот) - 12,60 \%, хамазулен (терпени) - 11,97 \%, пальмітинова кислота (жирні кислоти) - 8,28 \%. Головні компоненти листя: ситостерол (фітостероли) - 17,57 \%, 1-(2-гідрокси-5-метилфеніл)-етанон (кетон) - 8,35 \%, фітол (терпени) - 6,10 \%. Відомо, що хамазулен характеризується антиоксидантною, антиноцицептивною, цитотоксичною активністю. Для ситостеролу притаманна протизапальна й протидіабетична активність, гексадеканова (пальмітинова) кислота має протимікробну, протидіабетичну й антиоксидантну властивості. Для фітолу характерний широкий спектр біологічної дії: протимікробна, антиноцицептивна, протизапальна, антиоксидантна, цитотоксична.

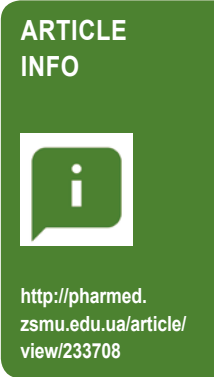

UDC 615.322:582.724.1].074:543.51 DOI: $10.14739 / 2409-2932.2021 .2 .233708$

Current issues in pharmacy and medicine: science and practice 2021; 14 (2), 179-184

Key words: Elaeagnus angustifolia, GS-MS, antimicrobial action, antidiabetic action, antinociceptive action, cytotoxic action, antiinflammatory action, biological activity.

*E-mail: bruttik2@gmail.com

Received: 20.04.2021 // Revised: 26.04.2021 // Accepted: 14.05.2021 
Висновки. Маслинку вузьколисту можна вважати джерелом протимікробних, антиноцицептивних, протизапальних, антиоксидантних, протидіабетичних і цитотоксичних препаратів.

Ключові слова: маслинка вузьколиста, GS-MS, протимікробна дія, протидіабетична дія, антиноцицептивна дія, цитотоксична дія, протизапальна дія, біологічна активність.

Current issues in pharmacy and medicine: science and practice 2021; 14 (2), 179-184

Хромато-масс-спектроскопическое исследование химического состава лоха узколистного Elaeagnus angustifolia L.

\author{
А. И. Панасенко, В. И. Мозуль, О. Н. Денисенко, И. И. Аксёнова, Т. В. Оберемко
}

Цель работы - хромато-масс-спектроскопическое исследование химического состава лоха узколистного плодов и листьев, определение перспектив применения этого растения в медицине.

Материалы и методы. Объекты исследования - лоха узколистного плоды и листья. Настойка получена методом мацерации, сырье экстрагировали метиловым спиртом при комнатной температуре в течение 10 дней в соответствии с методикой изготовления настоек. Химический состав Elaeagnus angustifolia L. изучен с помощью газового хроматографра Agilent 7890B GC System (Agilent, Санта-Клара, Калифорния, США) с масс-спектрометрическим детектором Agilent 5977 BGC/MSD (Agilent, Santa Clara, CA, США) и хроматографической колонки DB-5ms (30 м × 250 мкм × 0,25 мкм).

Результаты. Идентифицировали 23 соединения (одно в изомерном состоянии) в плодах и 20 соединений (два в изомерном состоянии) в листьях лоха узколистного. Основные компоненты плодов: ситостерол (фитостеролы) - 12,53 \%, пропил ацетат (эфиры карбоновых кислот) - 12,60 \%, хамазулен (терпены) - 11,97 \%, пальмитиновая кислота (жирные кислоты) - 8,28 \%. Главные компоненты листьев: ситостерол (фитостеролы) - 17,57 \%, 1 (2-гидрокси-5-метилфенил)-этанон (кетоны) - 8,35 \%, фитол (терпены) -6,10 \%. Известно, шо хамазулен обладает антиоксидантным, антиноцицептивным, цитотоксическим действием. Ситостеролу присуща противовоспалительная и противодиабетическая активность, гексадекановая (пальмитиновая) кислота обладает противомикробными, гипогликемическими и антиоксидантными свойствами. Для фитола характерен широкий спектр биологической активности: противомикробная, антиноцицептивная, противовоспалительная, антиоксидантная и цитотоксическая.

Выводы. Лох узколистный можно считать источником противомикробных, антиноцицептивных, противовоспалительных, антиоксидантных, противодиабетических и цитотоксических препаратов.

Ключевые слова: лох узколистный, противомикробное действие, противодиабетические средства, антиноцицептивное действие, цитотоксическое действие, противовоспалительное действие, биологическая активность.

Актуальные вопросы фармацевтической и медицинской науки и практики. 2021. Т. 14, № 2(36). С. 179-184

The family Eleagnaceae includes about 80 species of plants [1]. In forms of life, these are deciduous trees and shrubs, less often vines, which grow mainly in Western Europe, Asia Minor, Central, and Southeast Asia, the Far East, and North America [2]. These plants play a very important ecological role and are used in folk medicine in some eastern countries [3]. Of note is the narrow-leaved olive Elaeagnus angustifolia L. Thus, Iranian researchers have proven the effectiveness of aqueous extract of olive fruit in the treatment of osteoarthritis [4,5]. Scientists from the Tehran University of Medical Sciences have described the cardioprotective, antioxidant, analgesic, antitumor, and anti-inflammatory effects of olive extracts [6]. These data are confirmed by studies of a team of American and Iranian scientists [7]. Other Iranian scientists have studied the antioxidant effect and considered the possibility of using olives as a biological additive of probiotic nature [8].

However, it was not revealed sufficient information on the chemical composition of Elaeagnus angustifolia L. in the literature. Therefore, research in this area is expedient and relevant.

\section{Aim}

The purpose of our work is to study the chemical composition of olives of narrow-leaved fruits and leaves by chromato-mass spectroscopic and to catch out on further promising applications of this plant in medicine.

\section{Materials and methods}

The object of the study was fruits and leaves of narrow-leaved olives. Raw materials were collected in August 2020 during the flowering and fruiting phase (Zaporizhzhia, Vyrva tract).

The tincture was obtained by maceration, and the raw material was extracted with methyl alcohol at room temperature for 10 days according to the method of making tinctures. $0.1 \mathrm{ml}$ of the extract was placed in a $1 \mathrm{ml}$ micro flask and made up to $0.5 \mathrm{ml}$ with methanol [9].

Qualitative and quantitative determination of active compounds was carried out at the Department of Natural Sciences for Foreign Students and Toxicological Chemistry (Head of the Department - PhD, DSc, Professor O. I. Panasenko).

The completeness of the reactions and the individuality of the resulting compounds were controlled by the gas chromatograph Agilent 7890B with a 5977B mass spectrometry detector. The column is DB- $5 \mathrm{~ms} 30 \mathrm{~m} \times 250 \mu \mathrm{m} \times 0.25 \mu \mathrm{m}$ with length. The gas-carrier speed (helium) is $1.6 \mathrm{ml} / \mathrm{min}$. Injection volume $-0.5 \mu$ l. Separation of the flow is $1: 50$. The temperature of the sampling unit is $230^{\circ} \mathrm{C} \rightarrow 12^{\circ} \mathrm{C} / \mathrm{s} \rightarrow 275^{\circ} \mathrm{C}$. Thermostat temperature: programmable, $240{ }^{\circ} \mathrm{C}(1$ minute delay $) \rightarrow 5^{\circ} \mathrm{C} /$ $\min \rightarrow 280{ }^{\circ} \mathrm{C}$ (delay $1 \mathrm{~min}$.). The total time of examination is $10 \mathrm{~min}$. Temperature of interface GS/MS $-280{ }^{\circ} \mathrm{C}$; ion sources $-230^{\circ} \mathrm{C}$; quadrupole mass analyzer $-150^{\circ} \mathrm{C}$. Type of ionization: EI with an electron energy of $70 \mathrm{eV}$. The range of mass numbers that was scanned: $30-500 \mathrm{~m} / \mathrm{z}$. 


\section{Results}

According to the results of the study, 23 compounds ( 1 in the isomeric state) in fruits and 20 compounds ( 2 in the isomeric state) were identified in the leaf of Olive narrow-leaved (Tables 1, 2), which by chemical structure belong to different classes of organic substances. The largest part in the chemical composition of fruits, was esters of carboxylic acids (5 com- pounds, $24.32 \%$ ), heterocyclic COMPOUNDS (5 compounds, $14.53 \%$ ), phytosterols ( 1 compound, $12.53 \%$ ), terpenes (1 compound, $11.97 \%)$.

The main components of fruits were sitosterol (phytosterols) - $12.53 \%$, propyl acetate (esters of carboxylic acids) $-12.60 \%$, chamazulene (terpenes) $-11.97 \%$ and palmitic acid (fatty acids) $-8.28 \%$.

Table 1. Qualitative and quantitative composition of biologically active substances of Elaeagnus angustifolia L. fruit

\begin{tabular}{|c|c|c|c|}
\hline & RT, $\min$ & Compound label & Area sum \% \\
\hline 1. & 1.699 & Acetic acid, methyl ester & 2.02 \\
\hline 2. & 1.956 & n-Propyl acetate* & 10.44 \\
\hline 3. & 2.087 & 2-Propenoic acid, ethenyl ester & 1.19 \\
\hline 4. & 2.135 & n-Propyl acetate* & 2.16 \\
\hline 5. & 2.247 & Propanoic acid, 2-oxo-, methyl ester & 7.34 \\
\hline 6. & 3.183 & 2-Amino-1,3-propanediol & 5.99 \\
\hline 7. & 3.514 & 1,2-Cyclopentanedione & 2.99 \\
\hline 8. & 4.325 & 2-Hydroxy-gamma-butyrolactone & 5.72 \\
\hline 9. & 4.917 & (E,S)-2-Hexenoic acid, 4-amino-5-methyl-, methyl ester & 1.17 \\
\hline 10. & 5.137 & Furaneol & 2 \\
\hline 11. & 5.414 & Maltol & 1.16 \\
\hline 12. & 5.73 & sec-Butyl nitrite & 1.89 \\
\hline 13. & 6.244 & I-Alanine, N-methoxycarbonyl-, tridecyl ester & 1.14 \\
\hline 14. & 6.418 & 4H-Pyran-4-one, 2,3-dihydro-3,5-dihydroxy-6-methyl- & 6.97 \\
\hline 15. & 7.028 & 5-Hydroxymethyldihydrofuran-2-one & 1.44 \\
\hline 16. & 7.135 & Catechol & 1.18 \\
\hline 17. & 8.029 & 1,2-Benzenediol, 3-methyl- & 1.68 \\
\hline 18. & 8.608 & trans-2-undecenoic acid & 1.75 \\
\hline 19. & 10.521 & d-Glycero-d-galacto-heptose & 3.59 \\
\hline 20. & 14.001 & Chamazulene & 11.97 \\
\hline 21. & 16.248 & n-Hexadecanoic acid & 8.28 \\
\hline 22. & 17.21 & Pyridine, 4-(3-mercapto-4-methyl-5-(4H-1,2,4-triazolyl))- & 2.96 \\
\hline 23. & 17.934 & Octadec-9-enoic acid & 2.42 \\
\hline 24. & 22.312 & gamma.-Sitosterol & 12.53 \\
\hline
\end{tabular}

Table 2. Qualitative and quantitative composition of biologically active substances of Elaeagnus angustifolia L. leaves

\begin{tabular}{|l|l|l|l|}
\hline \multicolumn{1}{|l|}{ RT, $\min$} & Compound label & Area sum \% \\
\hline 1. & 1.713 & D-Alloisoleucine & 2.3 \\
\hline 2. & 1.959 & Isopropyl acetate & 2.13 \\
\hline 3. & 4.342 & 2-Octyn-1-ol, 7-[(tetrahydro-2H-pyran-2-yl)oxy]- & 1.73 \\
\hline 4. & 5.561 & 4-Heptanol, 4-ethyl-2,6-dimethyl- & 2.25 \\
\hline 5. & 7.467 & Benzofuran, 2,3-dihydro- & 5.99 \\
\hline 6. & 8.762 & Ethanone, 1-(2-hydroxy-5-methylphenyl)- & 8.35 \\
\hline 7. & 10.557 & d-Glycero-l-gluco-heptose & 1.87 \\
\hline 8. & 11.094 & .beta.-D-Glucopyranose, 1,6-anhydro- & 3.94 \\
\hline
\end{tabular}


Cont. of table 2.

\begin{tabular}{|l|l|l|l|}
\hline & RT, $\min$ & Compound label & Area sum \% \\
\hline 9. & 11.92 & Ethanone, 1-(3,4-dimethoxyphenyl)- & 3.44 \\
\hline 10. & 13.88 & Myo-Inositol, 2-C-methyl- & 5.43 \\
\hline 11. & 15.045 & 2-Pentadecanone, 6,10,14-trimethyl- & 5.5 \\
\hline 12. & 15.21 & 2-Pentanone, 4-(1,3,3-trimethyl-7-oxabicyclo[4.1.0]hept-2-yl)- & 2.79 \\
\hline 13. & 16.24 & n-Hexadecanoic acid & 5.23 \\
\hline 14. & 17.674 & Phytol & 6.1 \\
\hline 15. & 17.932 & Oleic Acid* & 2.21 \\
\hline 16. & 19.007 & Oleic Acid & 1.79 \\
\hline 17. & 19.792 & 4,8,12,16-Tetramethylheptadecan-4-olide & 1.76 \\
\hline 18. & 19.991 & Stigmasterol & 3.27 \\
\hline 19. & 21.498 & $9,19-C y c l o l a n o s t-7-e n-3-o l$ & 2.92 \\
\hline 20. & 22.316 & .gamma.-Sitosterol & 17.57 \\
\hline 21. & 24.617 & .alpha.-Tocospiro A & 4.37 \\
\hline 22. & 24.911 & .alpha.-Tocospiro A & 3.76 \\
\hline
\end{tabular}

*: these compounds are believed to be isomers.

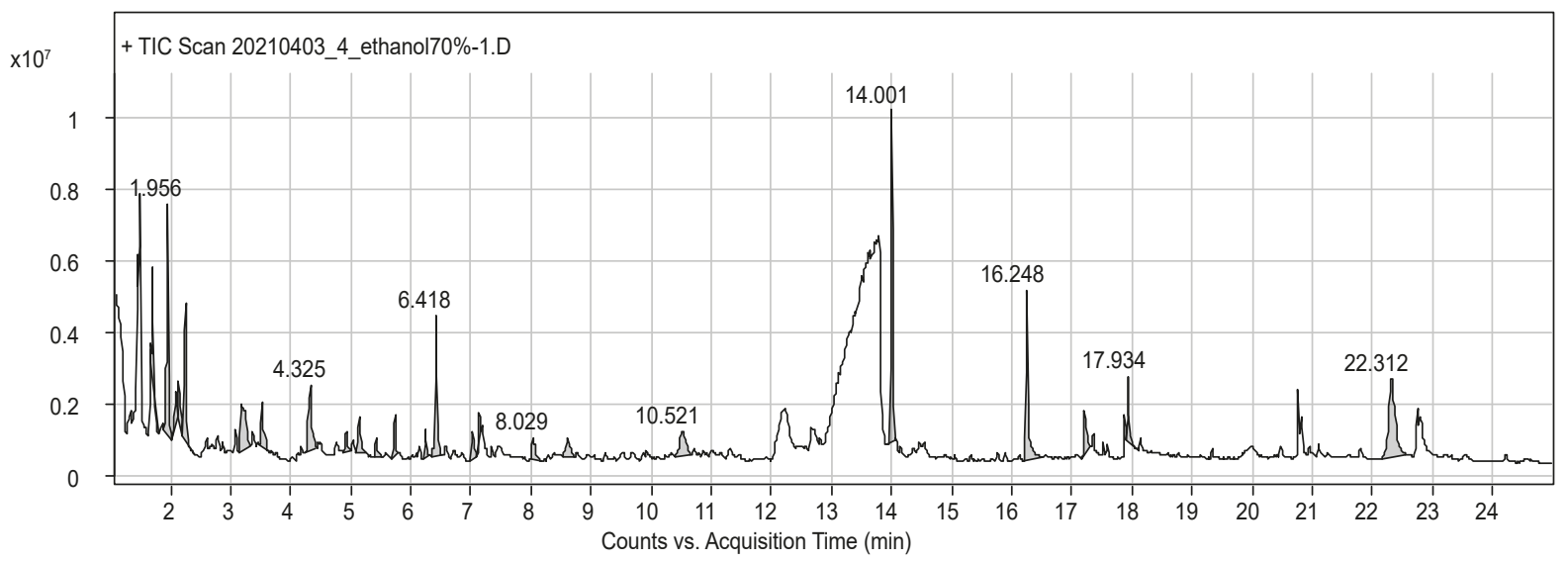

Fig. 1. Chromatogram of Elaeagnus angustifolia L. fruit's components.

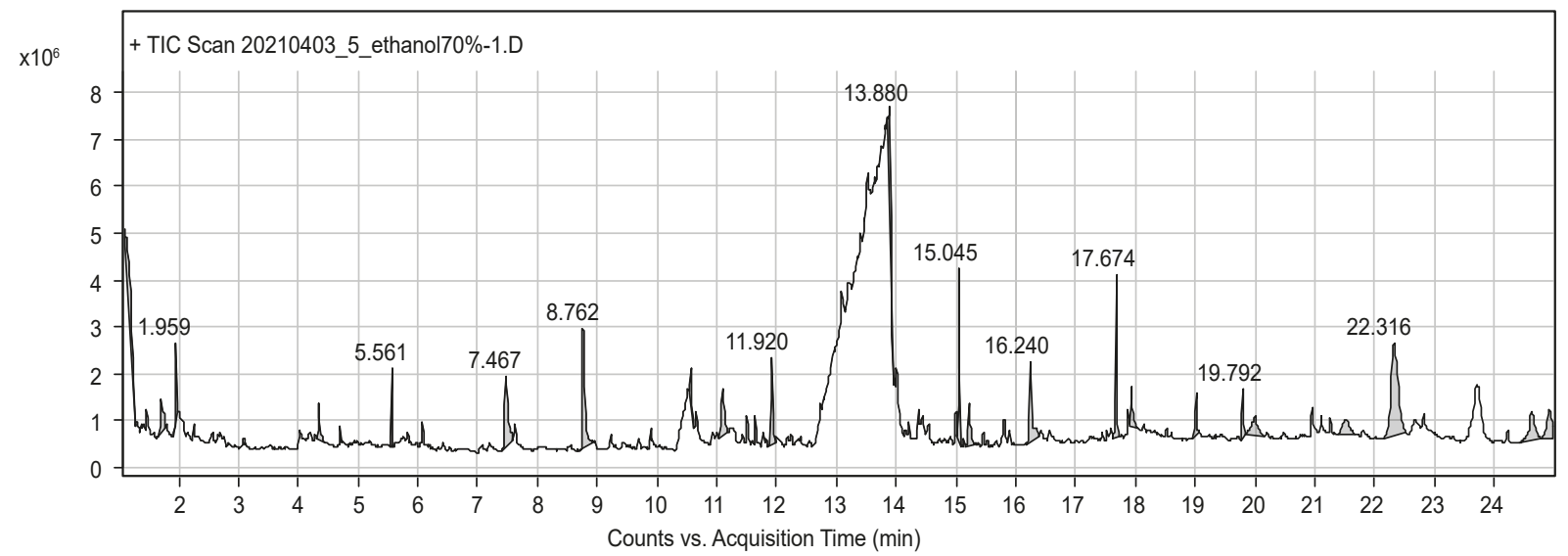

Fig. 2. Chromatogram of Elaeagnus angustifolia L. leaves' components. 
The chemical composition of the leaves slightly differed: the main share belonged to phytosterols (2 compounds, $20.87 \%$ ), ketones (4 compounds, $20.08 \%$ ), and terpenes ( 2 compounds, $14.23 \%$ ).

The main component of the leaves was sitosterol (phytosterols) - $17.57 \%, 1-(2$-hydroxy-5-methylphenyl)-ethanone(ketone) $-8.35 \%$, phytol (terpenes) $-6.10 \%$.

The chromatogram of fruit components (Fig. 1) was identified sitosterol $(\mathrm{RT}=22.312)$, palmitic acid $(\mathrm{RT}=16.248)$, chamazulene $(\mathrm{RT}=14.001)$, propyl acetate $(\mathrm{RT}=1.956)$.

The chromatogram of leaves components (Fig. 2) was identified sitosterol $(\mathrm{RT}=22.316)$, oleic acid $(\mathrm{RT}=17.934)$, palmitic acid $(\mathrm{RT}=16.240)$.

\section{Discussion}

According to the literature chamazulene has antioxidant [10] and antinociceptive activity [11]. Italian scientists have studied its effects on human melanoma cells, in which it was found that plants rich in chamazulene were particularly active against cancer cells, causing their death [12].

Sitosterol is characterized by anti-inflammatory activity $[13,14]$. Japanese scientists have examined its ability to inhibit chronic inflammation associated with obesity [15]. Based on the data obtained, it was concluded that sitosterol can be used to treat metabolic diseases, in particular diabetes [16].

Hexadecanoic (palmitic) acid has antimicrobial [17], antioxidant properties and can also be used in the treatment of diabetes [18].

Phytol is characterized by a wide range of biological activity, that is antimicrobial, antinociceptive, anti-inflammatory, antioxidant, and cytotoxic [19,20].

Based on the research, the olive can be considered as a source of antimicrobial, antinociceptive, anti-inflammatory, antioxidant, and cytotoxic medicines. Also, it can be considered useful in the treatment of diabetes.

\section{Conclusions}

1. For the first time the chemical composition of olive-leaved fruits and leaves was established with GS/MS.

2. According to the results of the study, 23 compounds ( 1 in the isomeric state) in fruits and 20 compounds ( 2 in the isomeric state) were identified in the leaf of Olive narrow-leaved, which by chemical structure belong to different classes of organic substances.

3 . The main components of fruits were sitosterol (phytosterols) $-12.53 \%$, propyl acetate (esters of carboxylic acids) - $12.60 \%$, chamazulene (terpenes) $-11.97 \%$ and palmitic acid (fatty acids) $-8.28 \%$. The main component of the leaves was sitosterol (phytosterols) - $17.57 \%$, 1-(2-hydroxy-5-methylphenyl)-ethanone (ketone) $-8.35 \%$, phytol (terpenes) $-6.10 \%$.

4. Olive narrow-leaved can be recommended for further research on antimicrobial, antinociceptive, anti-inflammatory, antioxidant, and cytotoxic, antidiabetic activity.
Prospects for further research. Olive narrow-leaved fruits and leaves can be considered as a potential source of antimicrobial, antinociceptive, anti-inflammatory, antioxidant, cytotoxic, and antidiabetic drugs.

Funding

The work is part of the joint integrated work of the Department of Pharmacognosy, Pharmacology and Botany of Zaporizhzhia State Medical University.

Conflicts of interest: authors have no conflict of interest to declare. Конфлікт інтересів: відсутній.

Information about authors:

Panasenko O. I., PhD, DSc, Professor, Head of the Department of Natural Sciences for Foreign Students and Toxicological Chemistry, Zaporizhzhia State Medical University, Ukraine.

ORCID ID: 0000-0002-6102-3455

Mozul V. I., PhD, Associate Professor of the Department of

Pharmacognosy, Pharmacology and Botany, Zaporizhzhia State Medical University, Ukraine.

Denysenko O. M., PhD, Associate Professor of the Department of

Pharmacognosy, Pharmacology and Botany, Zaporizhzhia State Medical

University, Ukraine.

Aksonova I. I., PhD, Teaching Assistant of the Department of

Pharmacognosy, Pharmacology and Botany, Zaporizhzhia State Medical

University, Ukraine.

ORCID ID: 0000-0002-3534-700X

Oberemko T. V., Director of the LLC "PMD-UKRAINE", Kyiv.

\section{Відомості про авторів:}

Панасенко О. І., д-р фарм. наук, професор, зав. каф. природничих дисциплін для іноземних студентів та токсикологічної хімії, Запорізький державний медичний університет, Україна.

Мозуль В. І., канд. фрарм. наук, доцент каф. фрармакогнозії, фармакології та ботаніки, Запорізький державний медичний університет, Україна.

Денисенко О. М., канд. фрарм. наук, доцент каф. фармакогнозії, фармакології та ботаніки, Запорізький державний медичний університет, Україна.

Аксьонова І. І., канд. фрарм. наук, асистент каф. фрармакогнозії, фармакології та ботаніки, Запорізький державний медичний університет, Україна.

Оберемко Т. В., директор ТОВ «ФМД-Україна», м. Київ.

\section{Сведения об авторах:}

Панасенко А. И., д-р фарм. наук, профессор, зав. каф. естественных дисциплин для иностранных студентов и токсикологической химии, Запорожский государственный медицинский университет, Украина.

Мозуль В. И., канд. фарм. наук, доцент каф. фармакогнозии, фармакологии и ботаники, Запорожский государственный медицинский университет, Украина.

Денисенко О. Н., канд. фарм. наук, доцент каф. фармакогнозии, фармакологии и ботаники, Запорожский государственный медицинский университет, Украина.

Аксёнова И. И., канд. фрарм. наук, ассистент каф. фрармакогнозии, фармакологии и ботаники, Запорожский государственный медицинский университет, Украина.

Оберемко Т. В., директор ООО «ФМД-Украина», г. Киев.

\section{References}

[1] Elaeagnus (n.d.). The Plant List. http://www.theplantlist.org/tpl1.1/ search?q=Elaeagnus

[2] Khadivi, A. (2018). Phenotypic characterization of Elaeagnus angustifolia using multivariate analysis. Industrial Crops and Products, 120 , 155-161. https://doi.org/10.1016/j.indcrop.2018.04.050 
[3] Nazir, N., Zahoor, M. \& Nisar, M. (2020). A Review on Traditional Uses and Pharmacological Importance of Genus Elaeagnus Species. The Botanical Review, 86, 247-280. https://doi.org/10.1007/ s12229-020-09226-y

[4] Panahi, Y., Alishiri, G. H., Bayat, N., Hosseini, S. M., \& Sahebkar, A. (2016). Efficacy of Elaeagnus Angustifolia extract in the treatment of knee osteoarthritis: a randomized controlled trial. EXCLI journal, 15, 203-210. https://doi.org/10.17179/excli2015-639

[5] Mahboubi, M. (2018). Elaeagnus angustifolia and its therapeutic applications in osteoarthritis. Industrial Crops and Products, 121, 36-45. https://doi.org/10.1016/.indcrop.2018.04.051

[6] Niknam, F., Azadi, A., Barzegar, A., Faridi, P., Tanideh, N., \& Zarshenas, M. M. (2016). Phytochemistry and Phytotherapeutic Aspects of Elaeagnus angustifolia L. Current drug discovery technologies, 13(4), 199-210. https://doi.org/10.2174/1570163813666160905115325

[7] Hamidpour, R., Hamidpour, S., Hamidpour, M., Shahlari, M., Sohraby, M., Shahlari, N., \& Hamidpour, R. (2017). Russian olive (Elaeagnus angustifolia L.): From a variety of traditional medicinal applications to its novel roles as active antioxidant, anti-inflammatory, anti-mutagenic and analgesic agent. Journal of Traditional and Complementary Medicine, 7(1), 24-29. https://doi.org/10.1016/j.jtcme.2015.09.004

[8] Sabouri, S., Rad, A. H., Peighambardoust, S. H., Fathipour, R. B. Feshangchi, J., Ansari, F., \& Pourjafar, H. (2021). The Oleaster (Elaeagnus angustifolia): A Comprehensive Review on Its Composition, Ethnobotanical and Prebiotic Values. Current pharmaceutical biotechnology, 22(3), 367-379. https://doi.org/10.2174/1389201020 666191107112243

[9] State Enterprise Ukrainian Scientific Pharmacopoeial Center of Medicines Quality. (2008, February 1). Derzhavna Farmakopeia Ukrainy. Dopovnennia 2 [The State Pharmacopoeia of Ukraine ( $1^{\text {st }}$ ed., Suppl. 1)]. Kharkiv: Naukovo-ekspertnyi farmakopeinyi tsentr. [in Ukrainian].

[10] Noori, K., Omidi, H., \& Pirahmadi, L. (2016). Morphological characteristics, essential oil, chamazulene percentage and anti-oxidation enzymes activity changes of chamomile Matricaria recutita L. under the soil and water salinity. Journal of Fundamental and Applied Sciences, 8(2S), 2293-2310.

[11] Reis Simas, D. L., Mérida-Reyes, M. S., Muñoz-Wug, M. A., Cordeiro, M. S., Giorno, T., Taracena, E. A., Oliva-Hernández, B. E., Martínez-Arévalo, J. V., Fernandes, P. D., Pérez-Sabino, J. F., \& Jorge Ribeiro da Silva, A. (2019). Chemical composition and evaluation of antinociceptive activity of the essential oil of Stevia serrata Cav. from Guatemala. Natural product research, 33(4), 577-579. https://doi.or $\mathrm{g} / 10.1080 / 14786419.2017 .1399376$

[12] Russo, A., Bruno, M., Avola, R., Cardile, V., \& Rigano, D. (2020). Chamazulene-Rich Artemisia arborescens Essential Oils Affect the Cell Growth of Human Melanoma Cells. Plants, 9(8), 1000. https:// doi.org/10.3390/plants9081000

[13] Liao, P. C., Lai, M. H., Hsu, K. P., Kuo, Y. H., Chen, J., Tsai, M. C. Li, C. X., Yin, X. J., Jeyashoke, N., \& Chao, L. K. (2018). Identification of $\beta$-Sitosterol as in Vitro Anti-Inflammatory Constituent in Moringa oleifera. Journal of agricultural and food chemistry, 66(41), 1074810759. https://doi.org/10.1021/acs.jafc. 8 b04555

[14] Paniagua-Pérez, R., Flores-Mondragón, G., Reyes-Legorreta, C. Herrera-López, B., Cervantes-Hernández, I., Madrigal-Santillán, O., Morales-González, J. A., Álvarez-González, I., \& Madrigal-Bujaidar, E. (2016). Evaluation of the anti-inflammatory capacity of beta-sitosterol in rodent assays. African journal of traditional, complementary, and alternative medicines : AJTCAM, 14(1), 123-130. https://doi.org/10.21010/aitcam.v14i1.13

[15] Kurano, M., Hasegawa, K., Kunimi, M., Hara, M., Yatomi, Y., Teramoto, T., \& Tsukamoto, K. (2018). Sitosterol prevents obesity-related chronic inflammation. Biochimica et biophysica acta. Molecular and cell biology of lipids, 1863(2), 191-198. https://doi.org/10.1016/j. bbalip.2017.12.004

[16] Babu, S., \& Jayaraman, S. (2020). An update on $\beta$-sitosterol: A potential herbal nutraceutical for diabetic management. Biomedicine \& pharmacotherapy = Biomedecine \& pharmacotherapie, 131, 110702. https://doi.org/10.1016/i.biopha.2020.110702

[17] Shaaban, M. T., Ghaly, M. F., \& Fahmi, S. M. (2021). Antibacterial activities of hexadecanoic acid methyl ester and green-synthesized silver nanoparticles against multidrug-resistant bacteria. Journal of basic microbiology, 61(6), 557-568. https://doi.org/10.1002/jobm.202100061

[18] Budiadji, A. F., Mapanawang, A. L., Sedeng, D., Muh, N., Tualeka, A., Fambrene, B. T., Ismail, Latuconcina, K. R., Djafar, Y., \& Daud, A. (2016). Identification of hexadecanoic acid compound which in golobe extract (Hornstedtiazingiberaceae). International Journal of Health Medicine and Current Research - ljhmcr, 1(1), 48-52.

[19] Lee, W., Woo, E. R., \& Lee, D. G. (2016). Phytol has antibacterial property by inducing oxidative stress response in Pseudomonas aeruginosa. Free radical research, 50(12), 1309-1318. https://doi.or $\mathrm{g} / 10.1080 / 10715762.2016 .1241395$

[20] Islam, M. T., Ali, E. S., Uddin, S. J., Shaw, S., Islam, M. A., Ahmed, M. I., Chandra Shill, M., Karmakar, U. K., Yarla, N. S., Khan, I. N., Billah, M. M., Pieczynska, M. D., Zengin, G., Malainer, C., Nicoletti, F., Gulei, D., Berindan-Neagoe, I., Apostolov, A., Banach, M., Yeung, A., ... Atanasov, A. G. (2018). Phytol: A review of biomedical activities. Food and chemical toxicology, 121, 82-94. https://doi. org/10.1016/j.fct.2018.08.032 